\title{
EVALUASI PELAKSANAAN PROGRAM SEAMOLEC DI SMK DAERAH ISTIMEWA YOGYAKARTA
}

\author{
Ahlusi Sunnah \\ SMKN5 Bengkulu Selatan \\ ahlusis@yahoo.co.id \\ Sukoco \\ Universitas Negeri Yogyakarta \\ sukocogd@yahoo.com
}

\begin{abstract}
Abstrak
Penelitian ini bertujuan untuk mengetahui pelaksanaan program SEAMOLEC di SMK Daerah Istimewa Yogyakarta (DIY) yaitu program kolaborasi e-learning, pertukaran siswa, pertukaran guru dan pelatihan guru ditinjau dari aspek: (1) context (, (2) input, (3) process, dan (4) product. Penelitian ini merupakan penelitian evaluasi yang menggunakan model CIPP (Context, Input, Process, and Product). Populasi dalam penelitian ini adalah sebelas SMK DIY yang telah menjalin kerjasama dengan Thailand Selatan. Sumber data adalah guru koordinator program SEAMOLEC di SMK DIY. Penelitian ini menggunakan sampel total. Pengumpulan data dalam penelitian ini menggunakan metode angket dan dokumentasi. Analisis validitas dengan validitas isi yaitu expert judgement. Teknik analisis data yang digunakan adalah analisis deskriptif. Hasil penelitian ini menunjukkan bahwa: pelaksanaan program SEAMOLEC di DIY ditinjau dari aspek: (1) context, termasuk dalam kategori sangat sesuai, yaitu relevan dengan latar belakang dan tujuan program; (2) input, termasuk dalam kategori sangat baik yaitu kesiapan SDM di sekolah dan biaya pelaksanaan program; (3) process, termasuk dalam kategori sangat, yaitu waktu pelaksanaan dan interaksi siswa dan guru; (4) product, termasuk dalam kategori sangat baik, yaitu dari segi hasil program. Faktor pendukung program yaitu sarana prasarana laboratorium komputer yang lengkap, dukungan kepala sekolah, dan penyelenggaraan pelatihan bahasa Thailand. Sedangkan faktor penghambat program yaitu dana yang masih sangat kurang.
\end{abstract}

Kata Kunci: evaluasi , CIPP, program SEAMOLEC

\section{AN EVALUATION OF SEAMOLEC PROGRAM IMPLEMENTATION IN YOGYAKARTA SPECIAL TERRITORY (DIY)}

\begin{abstract}
This study aims to determine the implementation of SEAMOLEC programs in SMK's in DIY which collaborative e-learning, student exchange programs, exchange teacher, and teacher training, in terms of the aspects of: (1) context, (2) input, (3) process, and (4) product. This study is an evaluation using the model of CIPP (Context, Input, Process, and Product). The population wast 11 vocational high schools (VHS) in DIY which have a partnership program with South Thailand. Data source is a teacher in the vocational program coordinator of SEAMOLEC in DIY. The research used the total sample. The data collection techniques in this study used questionnaires and documentation. The analysis of the validity of the content validity was through expert judgment. The data analysis used the descriptive analysis. The results of this study show that the program implementation of SEAMOLEC in DIY in terms of the aspect of: (1) context is in a very appropriate category, which is relevant to the background and objectives of the program; (2) input is in the an excellent category, which shows the readiness of the human resources in the school and the cost of the implementation of the program; (3) process is in the excellent category, which is execution time and the interaction of students and teachers; (4) product is in an excellentcategory, in terms of program outcomes. The supporting factors include the complete computer lab, the principal's support, and training and implementation of the language, while the inhibiting factor is the low fund for the program.
\end{abstract}

Keywords: evaluation, CIPP, program SEAMOLEC 


\section{PENDAHULUAN}

Pendidikan merupakan faktor utama dalam membangun karakter bangsa dan faktor untuk menggerakkan perekonomian suatu bangsa. Pendidikan adalah sebuah sistem yang terdiri atas berbagai komponen yang saling terkait dan sangat berperan penting dalam meningkatkan kualitas sumber daya manusia (SDM) karena dengan pendidikan diharapkan sumberdaya manusia mampu bersaing di era globalisasi yang penuh persaingan. Salah satu upaya peningkatan potensi pendidikan yang berkualitas adalah dengan memiliki networking lembaga pendidikan baik dalam negeri maupun luar negeri sehingga tujuan pendidikan nasional tercapai. Berdasarkan hasil Education For All Global Monitoring Report 2012 yang dikeluarkan oleh UNESCO atau disebut sebagai Organisasi Pendidikan, Ilmu Pengetahuan, dan Kebudayaan Perserikatan Bangsa-Bangsa setiap tahunnya, pendidikan Indonesia berada di peringkat ke-64 untuk pendidikan di seluruh dunia dari 120 negara (www.kampus.okezone. com). Dikutip dari laman Pearson, data The Learning Curve 2013 menunjukkan bahwa pendidikan Indonesia saat ini mengalami krisis dengan hasil pendidikan yang konsisten berada di peringkat bawah menurut tabel liga global yang diterbitkan oleh Lembaga Pendidikan Pearson (www.bbc.co.uk).

Di samping itu, menurut survei Political and Economic Risk Consultant (PERC), kualitas pendidikan di Indonesia berada pada urutan ke-12 dari 12 negara di Asia. Data yang dilaporkan The World Economic Forum Swedia, Indonesia hanya berpredikat sebagai follower bukan sebagai pemimpin teknologi dari 53 negara di dunia (www.edukasi. kompasiana.com). Salah satu penyebab buruknya pendidikan Indonesia adalah kualitas sumber daya manusia yang masih dibawah standar sehingga terjadi kesenjangan tingkat pendidikan khususnya antar negara di Asia Tenggara. Hal ini nantinya akan mempengaruhi tingkat profesional kerja.

Untuk mengatasi hal tersebut, perlu dilakukan upaya peningkatan mutu sumber daya manusia bidang pendidikan. Pemerintah Indonesia berupaya untuk mengatasi mutu pendidikan yang rendah dari negara-negara maju.
Solusi pemerintah melalui Direktorat Jendral Pendidikan Menengah Kementrian Pendidikan dan Kebudayaan untuk mengatasi permasalahan tersebut adalah dengan menerapkan program kerjasama mitra pendidikan dalam negeri dengan luar negeri sehingga pendidikan dalam negeri bisa bersinergi dengan pendidikan di Luar Negeri yang pendidikannnya sudah maju dan berkembang.

Tujuan jangka panjang dari program kerjasama mitra pendidikan tersebut adalah memberikan kesempatan kepada guru dan siswa kedua negara untuk mengenal lebih jauh sistem pendidikan di masing-masing negara terutama kurikulum dibidang vokasi, berinteraksi langsung dengan siswa, guru dan lingkungan sekolah, mempelajari kebudayaan dan meningkatkan keterampilan berbahasa baik bahasa Inggris maupun bahasa masing-masing negara (www.antaranews.com). Setiap negara yang terlibat kerjasama pendidikan dapat saling mendukung program kerjasama pendidikan tersebut sehingga tepat sasaran dan tercapai tujuan (edukasi.kompasiana.com). Program kerjasama mitra pendidikan dengan luar negeri ini bertujuan untuk membangun komunitas pendidikan untuk perbaikan mutu, dan sarana berbagi/bertukar ilmu pendidikan, serta sebagai sarana untuk belajar memahami kebudayaan dan kearifan lokal dari masing-masing negara.

Dengan adanya program kerjasama luar negeri diharapkan dapat menjembatani interaksi antar lembaga pendidikan di Asia Tenggara serta mensinergikan dan mengejar ketertinggalan kualitas pendidikan (Direktur Southeast Asian Minister Of Education Organization Regional Open Learning Centre/SEAMOLEC: Gatot Hari Priowirjanto) serta sekolah dapat mengambil manfaat dari keberadaan mitranya di luar negeri (Niputu, 2009, p.1). Kerjasama pendidikan untuk kawasan Asia Tenggara dijembatani oleh Organisasi Para Menteri Pendidikan se Asia Tenggara atau disebut SEAMOE (Southeast Asian Ministers of Education Organization). SEAMOE mendukung program kerjasama pendidikan vokasi jenjang pendidikan menengah dan tinggi untuk kawasan Asia Tenggara dengan tujuan meningkatkan kolaborasi antar SEAMO Negara Anggota dan lembaga mitra, memberikan kompetensi dan 
pengalaman personel dilengkapi dengan keahlian teknis yang diberikan oleh negara Anggota Asosiasi SEAMO. Kegiatan SEAMO difokuskan pada tema universal untuk pengembangan sumber daya manusia termasuk pengembangan berkelanjutan.

Tahun 2010 Indonesia-Thailand mengadakan kerjasama dibidang pendidikan khususnya untuk pendidikan vokasi yaitu School Partnership Program. Program tersebut diharapkan dapat membantu sekolah-sekolah yang ada di Indonesia belajar dari kemajuan sekolah mitra di luar negeri dan bisa menjadi alternatif upaya pemerintah daerah untuk mengejar ketertinggalan kualitas pendidikan. Hal tersebut diperkuat dari hasil penelitian yang menyatakan bahwa program kerjasama Luar Negeri sudah menjadi suatu budaya mutu (Rika, 2011, p.1). Jumlah sekolah yang telah melakukan kerjasama Luar Negeri di Indonesia sebanyak 19 SMK (Daerah Istimewa Yogyakarta, Bali dan Jawa Tengah) dengan 19 Collage Thailand pada tahun 2011. Tahun 2012 terjadi peningkatan jumlah kerjasama antara Indonesia-Thailand yaitu sebanyak 27 SMK dan 33 Collage (www.kemdiknas.go.id). Data diatas menunjukkan bahwa dari tahun ke tahun pemerintah khususnya pemerintah daerah terus berupaya meningkatkan mutu pendidikan terutama mutu pendidikan vokasi.

SMKdiDaerahIstimewaYogyakartaseperti dijelaskan diatas telah mengimplementasikan program kerjasama dengan sekolah luar negeri, namun pelaksanaannya belum optimal sehingga pemanfaatan dan penerapan yang dilakukan oleh sekolah belum berpengaruh terhadap siswa, guru dan sekolah. Rencana aksi yang diterapkan oleh SMK Daerah Istimewa Yogyakarta perlu dilakukan analisis dari setiap aksi rencana yang dipilih oleh pihak sekolah sebagai upaya perbaikan mutu pendidikan untuk guru, siswa, dan sekolah. Disamping itu belum diketahui bagaimana proses seleksi pemilihan pertukaran siswa dan guru ke luar negeri dan faktor apa saja yang mendukung dan menghambat selama berlangsungnya program kerjasama luar negeri. Analisis yang dilakukan bertujuan untuk mengetahui apakah rencana aksi tersebut dapat mencapai tujuan dari program SEAMOLEC dan tujuan pendidikan nasional.
Evaluasi menurut Cross (1973) dalam Sukardi (2011, p.1) menyatakan bahwa Evaluasi merupakan proses yang menentukan kondisi, dimana suatu tujuan telah dapat dicapai. Evaluasi juga merupakan proses memahami, memberi arti, mendapatkan, dan mengkomunikasikan suatu informasi bagi keperluan pengambil keputusan. Tujuan dari evaluasi menurut Fitzpatrick, dkk (201, p.13) adalah untuk membuat penilaian tentang nilai apa pun yang sedang dievaluasi. Dalam evaluasi pendidikan ada banyak model yang bisa digunakan untuk mengevaluasi suatu program namun tujuannya sama yaitu melakukan kegiatan pengumpulan data atau informasi yang berkenaan dengan objek yang dievaluasi, yang tujuannya menyediakan bahan bagi pengambil keputusan dalam menentukan tindak lanjut suatu program. Menurut klasifikasi model evaluasi berdasarkan tujuannya (Endang,2013, p.120) evaluasi CIPP termasuk model management analysis yang bertujuan untuk mengevaluasi keputusan/kebijakan seorang manajer. Dalam penelitian ini model evaluasi program yang dipilih adalah model CIPP untuk mengevaluasi pelaksanaan program yang diselenggarakan oleh SEAMOLEC untuk SMK di D.I. Yogyakarta.

Evaluasi context yang akan diteliti meliputi situasi/latar belakang program SEAMOLEC dan tujuan program dengan kebutuhan sekolah seperti program kolaborasi e-learning, pertukaran siswa, pertukaran guru dan pelatihan guru SMK di Daerah Istimewa Yogyakarta. Evaluasi input meliputi sumber yang diperlukan untuk mencapai tujuan umum dan tujuan khusus dari program SEAMOLEC. Informasiinformasi yang terkumpul selama tahap penilaian dapat digunakan. Evaluasi input dalam program SEAMOLEC ini meliputi karakteristik guru dan siswa, dan biaya pelaksanaan. Evaluasi process berkaitan dengan pelaksanaan program yaitu proses kolaborasi e-learning, proses pertukaran siswa, proses pertukaran guru, dan proses pelatihan guru. Evaluasi process berfungsi untuk membantu mengimplementasikan keputusan, sampai sejauh mana rencana diterapkan. Proses dalam suatu program dapat berlangsung apabila terdapat komponen-komponen yang tercakup dalam syarat terjalinnya SEAMOLEC dengan SMK di D.I. Yogyakarta yaitu: guru, siswa, dan hambatan 
dalam melaksanakan program SEAMOLEC. Evaluasi product terkait dengan hasil dari pelaksanaan program. Penilaian product ini bertujuan untuk menentukan seberapa jauh pelaksanaan program telah mencapai tujuan program. Evaluasi product diperlukan untuk mengetahui apakah program SEAMOLEC bermanfaat bagi siswa, guru dan sekolah.

Henry dan Thompson mendefiniskan pendidikan kejuruan dalam Berg (2002, p.45) Vocational education is "learning how to work", vocational education has been an effort to improve technical competence and to raise anindividual sposition in society through mastering his environment with technology. Additionally, vocational education is geared to the needs of the job market and thus is often seen as contribution to national economic strength. Inti dari pendapat Berg bahwa pendidikan kejuruan identik dengan belajar bagaimana bekerja.

SEAMOLEC dalah sebuah institusi di bawah naungan Organisasi Menteri Pendidikan Asia Tenggara atau disebut SEAMOE yang berhubungan dengan penelitian dan pengembangan, pelatihan, informasi dan pertukaran teknologi, berbagi keahlian dan sumber daya di dalam dan di luar daerah di bidang pendidikan terbuka dan pendidikan jarak jauh (PJJ) se Asia Tenggara. Direktur SEAMOLEC menyatakan bahwa kemitraan ini dibentuk agar sekolah-sekolah belajar bersama secara jarak-jauh dengan memanfaatkan teknologi informasi. Disamping itu ada bentuk kerjasama lainnya yaitu pertukaran siswa, pertukaran guru dan pelatihan guru. Tujuan pendirian SEAMOLEC adalah melakukan program yang relevan dan responsif terhadap kebutuhan nasional dan regional saat ini di bidang pembelajaran terbuka dan jarak jauh. Dalam formulasi yang lebih spesifik, tujuannya adalah untuk membantu negara-negara anggota SEAMEO dalam mempromosikan dan mendorong pembelajaran terbuka dan jarak jauh sebagai cara lain untuk memenuhi permintaan untuk pendidikan dan pelatihan.

Menurut Suhartini (2007, p.15) berbagai aspek pendidikan, baik yang berwujud teori maupun praktis, bisa mengalir dari bangsa yang satu kepada bangsa yang lain sebagi hal- hal yang dipinjam, lalu diadopsi dan diadaptasikan secara teori maupun praktis. Menurut UU No 20 Tahun 2003 terdapat model-model penyelenggaraan pendidikan dasar dan menengah di Indonesia. Ada empat jenis sekolah di Indonesia yang dapat digambarkan secara skematik dalam suatu kontinum. Dalam konteks ini jenis sekolah dilihat dari kedekatannya dengan kondisi lokal Indonesia (Direktorat Pembinaan SMK, 2006, p.61). Jenis sekolah tersebut yaitu sekolah nasional, Sekolah Berstandar Internasional (SBI), sekolah Franchise Asing dan sekolah asing. Penyelenggaraan kerjasama/kemitraan dengan lembaga pendidikan di luar negeri merupakan salah satu model penyelenggaran SBI dengan menerapkan Standar Nasional Pendidikan Indonesia plus pengayaan/ penguatan/ pendalaman internasional yang digali dari sekolah-sekolah/ lembagalembaga pendidikan dalam negeri dan luar negeri. Pada model kemitraan ini, sekolah exs RSBI tetap dipilih untuk bermitra dengan salah satu sekolah di luar negeri/negara maju yang telah memiliki reputasi internasional.

Program kerjasama pendidikan dengan luar negeri adalah salah satu upaya peningkatan mutu sumber daya manusia. Program kerjasama pendidikan diperuntukan bagi kemajuan negara khususnya kemajuan di bidang pendidikan. Penyelenggaraan program kerjasama pendidikan sangat bergantung pada biaya pendidikan karena pendidikan tanpa didukung biaya yang memadai, proses pendidikan di sekolah tidak akan berjalan sesuai harapan. Biaya pendidikan merupakan komponen masukan instrumental (instrument input) yang sangat penting dalam menyiapkan SDM melalui penyelenggaraan pendidikan di sekolah (Mulyono, 2010, p.23). Biaya pendidikan untuk program kerjasama SMK dengan sekolah luar negeri dikelola oleh sekolah penyelenggara secara efektif dan efisien untuk mencapai tujuan yang telah ditetapkan. Dengan terselenggaranya program kerjasama luar negeri diharapkan programprogram yang ada dapat menjembatani interaksi antar lembaga-lembaga pendidikan di Asia Tenggara pada jenjang sekolah menengah yaitu SMA, SMK maupun Madrasah Aliyah serta memfasilitasi percepatan interaksi antar guru dan pelajar di wilayah regional. 
Berdasarkan survey pendahuluan yang dilakukan di SMK D.I. Yogyakarta, penyelenggaran kemitraan dengan sekolah di luar negeri masih terjalin pasca pembubaran sekolah berstandar internasional. Hal ini dilakukan oleh sekolah demi tercapainya tujuan pendidikan nasional. Khusus untuk sekolah menengah kejuruan, kemitraan dengan luar negeri tidak terbatas dengan sekolah tetapi juga dengan lembaga-lembaga pelatihan, perusahaan-perusahaan dan lembaga-lembaga sertifikat seperti IMO dan ISO. Model mitra ini diimplementasikan oleh sekolah untuk memformulasikan penyelenggaraan sekolah, mulai dari perumusan mutu lulusan yang diharapkan, penyusunan kurikulum, pengembangan model pembelajaran dan penyiapan sekolah. berikut ini adalah program kemitraan untuk membangun kerjasama antara sekolah di Indonesia dengan negara Asia Tenggara dijelaskan dalam empat rencana aksi yaitu: (1) aksi kolaborasi e-learning; (2) aksi pertukaran siswa; (3) aksi pertukaran guru; (4) aksi pelatihan bersama untuk guru, kepala sekolah, dan tenaga kependidikan lainnya.

Pengertian e-learning menurut Horton (2001, p.1) yaitu: "E-learning is the use of internet and digital technologies to create experiences that educate our fellow human beings".

E-learning adalah penggunaan internet dan teknologi digital yang menciptakan pengalaman mendidik manusia. Pengalaman yang diperoleh dapat diformulasikan, diorganisasikan, dikemas dan dipasarkan. Menurut Clark Adrich (2004: 4), "A broad combination of processes, content, and infrastructure to usecomputers and networks to scale and/or improve one or more significant parts of a learning value chain, including management and delivery".

Pendapat tersebut menekankan pada definisi e-learning pada kerangka berfikir penggunaan jaringan komputer. Berdasarkan pendapat diatas dapat diambil kesimpulan bahwa e-learning adalah penggunaan teknologi komputer dan jaringan untuk menciptakan pengalaman mendidik manusia atau dengan kata lain bahwa e-learning merupakan proses pengaplikasian kegiatan komunikasi, pendidikan dan pelatihan secara elektronik sehingga dapat diakses oleh siapa saja dan kapan saja.
Pembelajaran kolaborasi merupakan pembelajaran yang mengacu kepada proses sosial dan kognitif untuk membentuk peserta didik berinteraksi satu sama lain. Kolaborasi peserta didik dalam pembelajaran didukung dengan alat rancang yang tepat yaitu alat berbasis komputer untuk komunikasi dan kolaborasi (Daradoumis, 2009, p.1). Pembelajaran kolaboratif membantu siswa untuk membangun pengetahuan mereka secara efektif dan meningkatkan berfikir kritis dan keterampilan pemecahan masalah dalam jurnal educational technology (Graham dan Scarborough, 1999, p.20). Dalam program SEAMOLEC, e-learning berfungsi untuk meningkatkan kualitas pembelajaran melalui studi kolaboratif, menyediakan jalur bagi guru melakukan penelitian dan berbagi pengetahuan, budaya dan nilai-nilai. Untuk memenuhi tujuan tersebut, beberapa kegiatan yang dapat dimasukkan ke dalam rencana aksi sekolah mitra yaitu kolaborasi e-learning dalam mata pelajaran tertentu (Matematika, Bahasa Inggris, Bahasa lain selain bahasa Inggris, Sains, dan Teknologi Mobile Game) melalui pembelajaran terbuka dan jarak jauh yang diberikan oleh SEAMOLEC. Dalam penelitian yang dilakukan oleh Wanwan M, dalam Jurnal Teknologi (2013, p.74), kelancaran kolaborasi e-learning dengan suatu media dipengaruhi oleh beberapa faktor seperti aksesibilitas internet dan kecepatan akses. Berdasarkan penelitian tersebut diatas dapat diartikan bahwa faktor penting dalam penyelenggaraan kolaborasi e-learning adalah aksesibilitas internet dan kecepatan akses. Hal ini dapat dijadikan pertimbangan atau yang melatarbelakangi adanya program kolaborasi e-learning. Menurut Waluyanti (2010, p.8) dalam proses kolaborasi antar siswa, guru dapat terlibat didalamnya secara tidak langsung, membantu proses kolaborasi dengan cara memberikan arahan berupa pesan untuk memecahkan masalah, sehingga kolaborasi menjadai lancar. Collaborative learning secara online dapat dilakukan dengan memanfaatkan program edmodo. Edmodo merupakan salah satu media yang menjadi prioritas program SEAMOLEC dalam pembelajaran bersama untuk SMK di D.I. Yogyakarta. Kolaborasi e-learning ditinjau dari aspek contexs, input, process, dan product dengan menggunakan 
metode Evaluasi CIPP adalah: (1) aspek context, pada aspek ini dilihat dari latar belakang dan relevansi tujuan program dengan kebutuhan sekolah; (2) aspek input, meliputi guru, siswa dan dana; (3) aspek process, meliputi interaksi proses pembelajaran; (4) aspek product, meliputi content pembelajaran yang disepakati sebagai colaboratif learning.

Sekolah dapat memberikan pengalaman yang banyak ke pada siswanya dengan berbagai cara, salah satunya adalah dengan program pertukaran siswa ke luar negeri (Wagner, 2009, p.65). Definisi pertukaran siswa sekolah menengah menurut Schewe adalah seseorang yang berusia delapan belas tahun atau lebih muda, yang melakukan perjalanan ke luar negeri untuk tinggal disana dan menghadiri sekolah setempat (Schewe, 2012, p.3). Menurut Faelli R, (2006, p.5) pertukaran siswa merupakan pembelajaran tentang perbedan negara, orang dan kultur, yang memberikan kesempatan untuk bertemu dengan orang dari berbagai negara. Disamping itu dapat mempertemukan dan berbagi pikiran dan ide dengan siswa di berbagai dunia. dari penjelasan diatas dapat diambil kesimpulan bahwa pertukaran siswa adalah kegiatan yang diikuti oleh siswa di luar negeri dalam pembelajaran untuk berbagi pikiran dan ide dengan siswa di berbagai dunia. Banyak manfaat yang akan diperoleh siswa dalam program pertukaran (Hansel, 2007, p.1). Persiapan akan membantu menghadapi tantangan, masalah, dan situasi yang sulit. Secara keseluruhan, persiapan yang baik akan menjadi landasan untuk sukses (Schewe, 2012, p.42). Siswa terpilih dalam program pertukaran siswa akan melalui proses seleksi baik tes atau wawancara atau yang telah direkomendasikan oleh gurunya (Hansel, 2007, p.5). Evaluasi Pertukaran siswa ditinjau dari aspek contexs, input, process, dan product dengan metode Evaluasi CIPP adalah: (1) aspek context, pada aspek ini dilihat dari latar belakang pelaksanaan program pertukaran siswa dan relevansi tujuan program terhadap kebutuhan sekolah; (2) aspek input, meliputi siswa dan dana penyelenggaraan program; (3) aspek process, meliputi kegiatan pelaksanaan pembelajaran; (4) aspek product, meliputi sikap dan pengetahuan siswa.

Menurut Chapman dan Thiel (1999, p.469), program pertukaran guru adalah program untuk mendapatkan pemahaman budaya dan pengetahuan tentang praktik pendidikan di seluruh dunia, sehingga secara langsung memunculkan ide yang mempengaruhi pengajaran mereka dan kehidupan siswa mereka. Perencanaan yang matang, baik pada bagian dari masing-masing guru serta sekolah-sekolah yang terlibat adalah salah satu prasyarat untuk keberhasilan dari pertukaran guru (Turner, 2003, pp. 268-269). Program pertukaran guru berfungsi untuk menunjang profesionalisme guru karena guru dapat memperoleh pengalaman lebih banyak dengan mengajar di tempat yang memiliki kultur dan keadaan sosial yang berbeda (Arief, 2013, p.1). Negara yang menjadi tujuan untuk program pertukaran guru adalah negara Thailand bagian selatan. Evaluasi pertukaran guru ditinjau dari aspek context, input, process, dan product dengan metode Evaluasi CIPP adalah: (1) aspek konteks, pada aspek ini dilihat dari latar belakang pelaksanaan program pertukaran guru dan relevansi tujuan program dengan sekolah luar negeri terhadap kebutuhan sekolah; (2) aspek input, meliputi guru dan dana; (3) aspek process, meliputi kegiatan pelaksanaan pembelajaran; (4) aspek product, meliputi peningkatan pengalaman dan kompetensi guru.

Eksistensi guru yang kompeten dan profesional merupakan syarat mutlak hadirnya sistem dan praktik pendidikan yang berkualitas. Hampir semua bangsa di dunia ini selalu mengembangkan kebijakan yang mendorong keberadaan guru yang berkualitas. Salah satu kebijakan yang dikembangkan oleh pemerintah di banyak negara adalah dengan menempatkan bidang pendidikan sebagai bidang yang perlu mendapat perhatian khusus dengan menyediakan hardware \& software yang memadai (Mugara R, 2011, p.1). Menurut Mangkuprawira dalam Rahman (2009, p.18) menyatakan bahwa pelatihan bagi karyawan merupakan sebuah proses mengajarkan pengetahuan dan keahlian tertentu serta sikap agar karyawan semakin terampil dan mampu melaksanakan tanggung jawabnya semakin baik, sesuai dengan standar. Pelatihan didefinisikan sebagai sistematis, pengembangan sikap, pengetahuan, keterampilan, pola perilaku yang dibutuhkan seorang individu 
untuk melakukan pekerjaan atau tugas yang memadai (Ranga, 2008, p.8). Seorang guru harus memiliki pengetahuan, metode dan teknik dalam mengajar dan merupakan faktor yang sangat mempengaruhi. Jadi dengan adanya pelatihan, guru memperoleh pengetahuan yang penting sesuai dengan kebutuhan bidangnya (Ranga, 2008: 8). Menurut Bansal (2009, p.1), pelatihan guru merupakan komponen integral dari sistem pendidikan. Evaluasi pelatihan guru ditinjau dari aspek contexs, input, process, dan product dengan metode Evaluasi CIPP adalah; (1) aspek contexs, pada aspek ini dilihat dari latar belakang pelaksanaan program pelatihan guru dan relevansi tujuan program pelatihan guru terhadap kebutuhan; (2) aspek input, meliputi guru dan dana; (3) aspek process, meliputi kegiatan pelaksanaan pelatihan yaitu kesesuaian materi dengan kebutuhan peserta; (4) aspek produk, meliputi penguasaan materi.

\section{METODE PENELITIAN}

Jenis penelitian ini adalah penelitian evaluasi. Pada penelitian ini, evaluasi dilakukan terhadap empat komponen yaitu context, input, process, dan poduct. Model evaluasi yang digunakan adalah CIPP untuk mengevaluasi pelaksanaan program SEAMOLEC di SMK D.I.Yogyakarta yang mejalin kerjasama dengan collage of education Thailand. Populasi dalam penelitian ini adalah 11 SMK di D.I.
Yogyakarta, yang telah melaksanakan program SEAMOLEC yaitu SMKN 2 Depok, SMKN 2 Pengasih, SMKN 1 Bantul, SMKN 2 Wonosari, SMK YAPI, SMK 3 Muhammadiyah, SMKN 2 Yogyakarta, SMKN 5 Yogyakarta, SMKN 1 Depok, SMKN 4 Yogyakarta, SMKN 6 Yogyakarta. Jumlah responden dari 11 SMK D.I.Yogyakarta adalah sebanyak 44 guru. Pengumpulan data dengan menggunakan angket untuk mengetahui tingkat perubahan siswa, guru dan dana terhadap pelaksanaan program SEAMOLEC serta mengungkap faktor penghambat dan faktor pendukung dari program tersebut.

\section{HASIL PENELITIAN DAN PEMBAHASAN}

Berdasarkan hasil analisis statistik deskriptif, dapat dideskripsikan karakteristik dan tingkat kecenderungan masing-masing aspek penelitian dari setiap program sebagai berikut:

\section{Program Kolaborasi E-learning}

\section{Aspek Context}

Butir Instrumen angket terdiri dari 6 butir pertanyaan dengan 4 butir pilihan jawaban. Berdasarkan rumus kategori data, diperoleh hasil disribusi frekuensi aspek context pada tabel berikut ini:

Tabel 1. Distribusi Frekuensi Aspek Context

\begin{tabular}{ccccc}
\hline No & Interval Nilai & Frekuesi & $\mathbf{( \% )}$ & Kategori \\
\hline 1 & $\mathrm{X} \geq 18$ & 8 & 72,73 & Sangat Baik \\
2 & $18>\mathrm{X} \geq 15$ & 2 & 18,18 & Baik \\
3 & $15>\mathrm{X}>12$ & 0 & 0 & Tidak Baik \\
4 & $\mathrm{X}<12$ & 1 & 9,09 & Sangat Tidak Baik \\
\hline & Total & $\mathbf{1 1}$ & $\mathbf{1 0 0}$ & \\
\hline
\end{tabular}

Perolehan skor berdasarkan tabel 1 menunjukkan bahwa 8 unit sekolah ditinjau dari aspek context program kolaborasi e-learning sangat baik (72,73\%), 2 sekolah dalam kategori baik (18,18\%), 0 sekolah dalam kategori tidak baik $(0 \%)$, dan 1 sekolah dalam kategori sangat tidak baik (9,09\%). Artinya bahwa ada satu sekolah yang sangat tidak mendukung terselenggaranya kolaborasi e-learning dari aspek context. Perolehan persentase diatas dapat dilihat dengan diagram Chart sebagai berikut. 


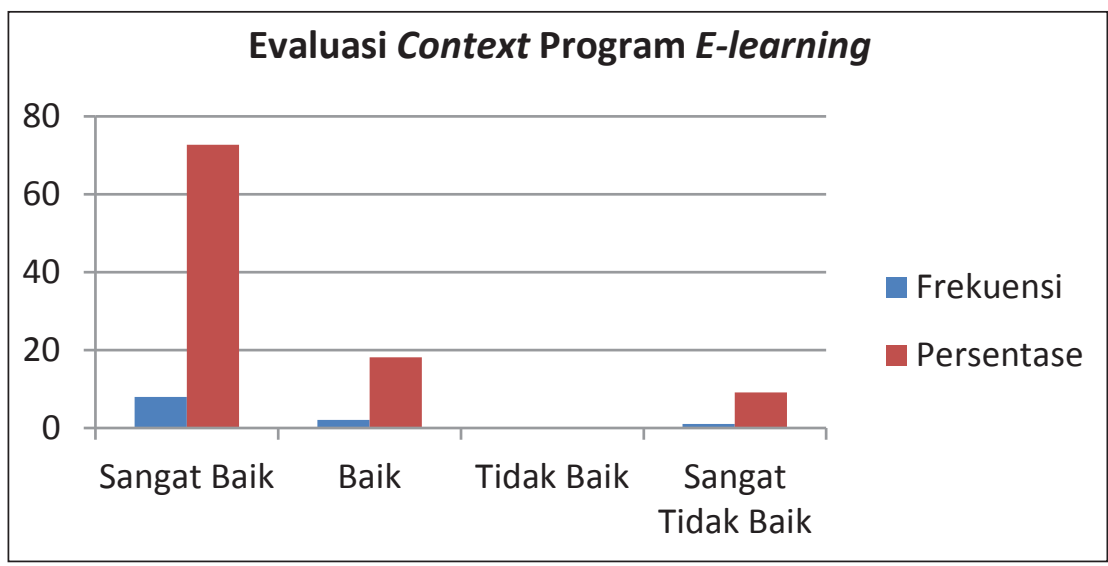

Gambar 1. Diagram Aspek Context

Tabel 2. Nilai Pencapaian Aspek Context

\begin{tabular}{cccccc}
\hline Jumlah Responden & Jumlah Soal & Total Skor & NPK & Persentase (\%) & Keterangan \\
\hline 11 & 6 & 198 & 18 & 75 & Sangat Sesuai \\
\hline
\end{tabular}

Tabel 3. Distribusi Frekuensi Aspek Input

\begin{tabular}{ccccc}
\hline No & Interval Nilai & Frekuensi & $\mathbf{( \% )}$ & Kategori \\
\hline 1 & $\mathrm{X} \geq 11$ & 9 & 81,82 & Sangat Baik \\
2 & $11>\mathrm{X} \geq 7,5$ & 0 & 0 & Baik \\
3 & $7,5>\mathrm{X} \geq 4,0$ & 2 & 18,18 & Tidak Baik \\
4 & $\mathrm{X}<4,0$ & 0 & 0 & Sangat Tidak Baik \\
\hline Total & & $\mathbf{1 1}$ & $\mathbf{1 0 0}$ & \\
\hline
\end{tabular}

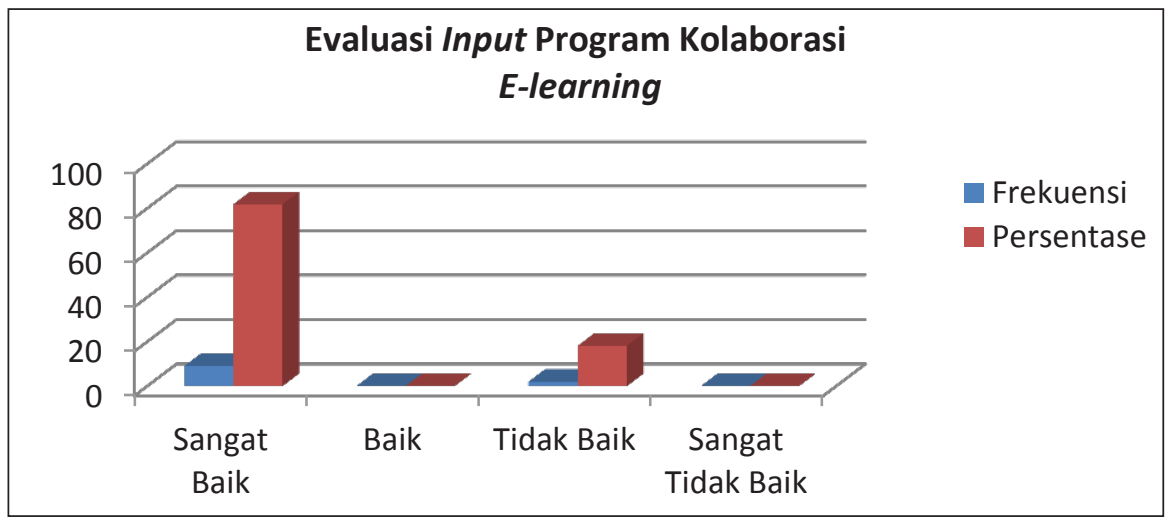

Gambar 2. Diagram Aspek Input

Berdasarkan tabel 2, diperoleh persentase nilai yang dicapai sebesar $75 \%$ dengan kategori sangat sesuai.

\section{Aspek Input}

Butir Instrumen angket terdiri dari 7 butir pertanyaan dengan 4 butir pilihan jawaban.
Berdasarkan rumus kategori data, diperoleh hasil disribusi frekuensi aspek input pada dapat dilihat pada tabel 3 .

Perolehan skor berdasarkan tabel 3 menunjukkan bahwa 9 sekolah ditinjau dari aspek input program kolaborasi e-learning sangat baik $(81,82 \%), 2$ sekolah dalam kategori ti- 
Tabel 4. Nilai Pencapaian Aspek Input

\begin{tabular}{cccccc}
\hline Jumlah Responden & Jumlah Soal & Total Skor & NPK & Persentase (\%) & Keterangan \\
\hline 11 & 7 & 200 & 18,18 & 64,93 & Sangat Baik \\
\hline
\end{tabular}

Tabel 5. Distribusi Frekuensi Aspek Process

\begin{tabular}{clccc}
\hline No & Interval Nilai & Frekuensi & $\mathbf{( \% )}$ & Kategori \\
\hline 1 & $\mathrm{X} \geq 39$ & 0 & 0 & Sangat Baik \\
2 & $39>\mathrm{X} \geq 32,5$ & 0 & 0 & Baik \\
3 & $32,5>\mathrm{X} \geq 26$ & 0 & 0 & Tidak Baik \\
$4 \quad \mathrm{X}<26$ & 11 & 100 & Sangat Tidak Baik \\
\hline Total & $\mathbf{1 1}$ & $\mathbf{1 0 0}$ & \\
\hline
\end{tabular}

Tabel 6. Distribusi Frekuensi Aspek Product

\begin{tabular}{llccc}
\hline No & Interval Nilai & Frekuensi & $(\%)$ & Kategori \\
\hline 1 & $\mathrm{X} \geq 12$ & 0 & 0 & Sangat Baik \\
2 & $12>\mathrm{X} \geq 10$ & 0 & 0 & Baik \\
3 & $10>\mathrm{X} \geq 8$ & 0 & 0 & Tidak Baik \\
$4 \quad \mathrm{X}<8$ & 0 & 100 & Sangat Tidak Baik \\
\hline \multicolumn{2}{l}{ Total } & 11 & 100 & \\
\hline
\end{tabular}

dak baik (18,18\%). Artinya bahwa dua sekolah dari aspek input tidak mendukung terselenggaranya kolaborasi e-learning. Perolehan persentase diatas dapat dilihat dengan diagram Chart pada gambar 2 .

Berdasarkan tabel 4, diperoleh persentase nilai yang dicapai sebesar $64,93 \%$ dengan kategori sangat baik.

\section{Aspek Process}

Butir Instrumen angket terdiri dari 13 butir pertanyaan dengan 4 butir pilihan jawaban. Berdasarkan rumus kategori data, diperoleh hasil disribusi frekuensi aspek process dapat dilihat pada tabel 5 .

Perolehan skor berdasarkan tabel 5 menunjukkan bahwa 11 sekolah ditinjau dari aspek process program kolaborasi e-learning sangat tidak baik (100\%). Artinya bahwa 11 sekolah dari aspek process tidak menyelenggarakan kolaborasi e-learning. Untuk nilai pencapaian hasil program kolaborasi e-learning aspek process tidak diperoleh karena tidak terselenggara.

\section{Aspek Product}

Butir Instrumen angket terdiri dari 13 butir pertanyaan dengan 4 butir pilihan jawaban. Berdasarkan rumus kategori data, diperoleh hasil disribusi frekuensi aspek product pada tabel berikut ini:

Perolehan skor berdasarkan tabel 6 menunjukkan bahwa 11 sekolah ditinjau dari aspek product program kolaborasi e-learning sangat tidak baik (100\%). Artinya bahwa 11 sekolah dari aspek product tidak memperoleh hasil output karena tidak menyelenggarakan program kolaborasi e-learning.

\section{Program Pertukaran Siswa}

\section{Aspek Context}

Butir Instrumen angket terdiri dari 5 butir pertanyaan dengan 4 butir pilihan jawaban. Berdasarkan rumus kategori data, diperoleh hasil disribusi frekuensi aspek context dapat dilihat pada tabel 7. 
Tabel 7. Distribusi Frekuensi Aspek Context

\begin{tabular}{clccc}
\hline No & Interval Nilai & Frekuesi & $\mathbf{( \% )}$ & Kategori \\
\hline 1 & $\mathrm{X} \geq 15$ & 10 & 90,91 & Sangat Baik \\
2 & $15>\mathrm{X} \geq 12,5$ & 1 & 9,09 & Baik \\
3 & $12,5>\mathrm{X}>10$ & 0 & 0 & Tidak Baik \\
$4 \quad \mathrm{X}<10$ & 0 & 0 & Sangat Tidak Baik \\
\hline Total & $\mathbf{1 1}$ & $\mathbf{1 0 0}$ & \\
\hline
\end{tabular}

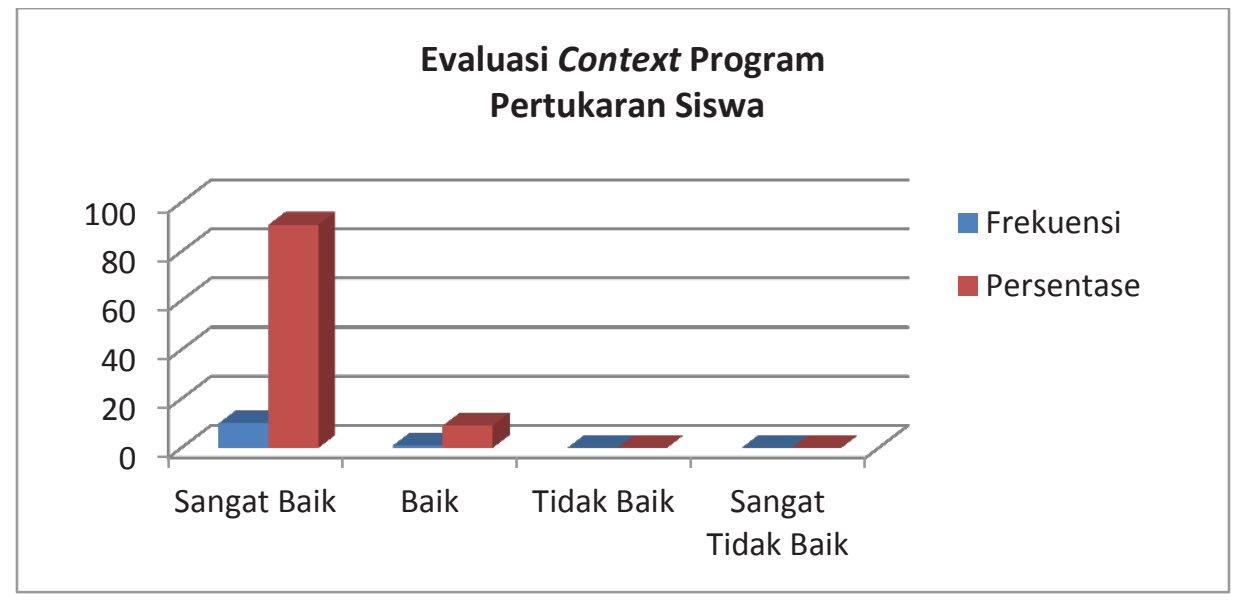

Gambar 3. Diagram Aspek Context

Tabel 8. Nilai Pencapaian Aspek Context

\begin{tabular}{cccccc}
\hline Jumlah Responden & Jumlah Soal & Total Skor & NPK & Persentase (\%) & Keterangan \\
\hline 11 & 4 & 173 & 15,73 & 98,31 & Sangat Sesuai \\
\hline
\end{tabular}

Tabel 9. Distribusi Frekuensi Aspek Input

\begin{tabular}{llccc}
\hline No & Interval Nilai & Frekuensi & $\mathbf{( \% )}$ & Kategori \\
\hline 1 & $\mathrm{X} \geq 11$ & 11 & 100 & Sangat Baik \\
2 & $11>\mathrm{X} \geq 7,5$ & 0 & 0 & Baik \\
3 & $7,5>\mathrm{X} \geq 4,0$ & 0 & 0 & Tidak Baik \\
4 & $\mathrm{X}<4,0$ & 0 & 0 & Sangat Tidak Baik \\
\hline \multicolumn{2}{l}{ Total } & 11 & 100 & \\
\hline
\end{tabular}

Perolehan skor berdasarkan tabel 7 menunjukkan bahwa 10 unit sekolah ditinjau dari aspek context program pertukaran siswa sangat baik $(90,91 \%) 1$ sekolah. 1 sekolah dalam kategori baik (9,09\%). Perolehan persentase diatas dapat dilihat dengan diagram Chart yang dapat dilihat pada gambar 3.

Berdasarkan tabel 8, diperoleh persentase nilai yang dicapai sebesar $98,31 \%$ dengan kategori sangat sesuai.

\section{Aspek Input}

Butir Instrumen angket terdiri dari 7 butir pertanyaan dengan 4 butir pilihan jawaban. Berdasarkan rumus kategori data, diperoleh hasil disribusi frekuensi aspek input dapat dilihat pada tabel tabel 9 .

Perolehan skor berdasarkan tabel 9 menunjukkan bahwa 11 sekolah ditinjau dari aspek input program pertukaran siswa sangat baik $(100 \%)$. Artinya bahwa 11 sekolah dari aspek 
Tabel 10. Nilai Pencapaian Aspek Input

\begin{tabular}{cccccc}
\hline Jumlah Responden & Jumlah Soal & Total Skor & NPK & Persentase (\%) & Keterangan \\
\hline 11 & 7 & 249 & 22,64 & 80,85 & Sangat Baik \\
\hline
\end{tabular}

Tabel 11. Distribusi Frekuensi Aspek Process

\begin{tabular}{clccc}
\hline No & Interval Nilai & Frekuensi & $\mathbf{( \% )}$ & Kategori \\
\hline 1 & $\mathrm{X} \geq 11$ & 11 & 100 & Sangat Baik \\
2 & $11>\mathrm{X} \geq 7,5$ & 0 & 0 & Baik \\
3 & $7,5>\mathrm{X} \geq 4$ & 0 & 0 & Tidak Baik \\
$4 \quad \mathrm{X}<4$ & 0 & 0 & Sangat Tidak Baik \\
\hline \multicolumn{2}{l}{ Total } & 11 & 100 & \\
\hline
\end{tabular}

Tabel 12. Nilai Pencapaian Aspek Input

\begin{tabular}{cccccc}
\hline Jumlah Responden & Jumlah Soal & Total Skor & NPK & Persentase (\%) & Keterangan \\
\hline 11 & 7 & 249 & 22,64 & 80,85 & Sangat Baik \\
\hline
\end{tabular}

Tabel 13. Distribusi Frekuensi Aspek Product

\begin{tabular}{clccc}
\hline No & Interval Nilai & Frekuensi & $\mathbf{( \% )}$ & Kategori \\
\hline 1 & $\mathrm{X} \geq 12$, & 11 & 100 & Sangat Baik \\
2 & $12,0>\mathrm{X} \geq 10,0$ & 0 & 0 & Baik \\
3 & $10,0>\mathrm{X} \geq 8,0$ & 0 & 0 & Tidak Baik \\
$4 \quad \mathrm{X}<8,0$ & 0 & 0 & Sangat Tidak Baik \\
\hline Total & 11 & 100 & \\
\hline
\end{tabular}

input sangat mendukung terselenggaranya program pertukaran siswa.

Berdasarkan tabel 10, diperoleh persentase nilai yang dicapai sebesar $80,85 \%$ dengan kategori sangat baik.

\section{Aspek Process}

Butir Instrumen angket terdiri dari 7 butir pertanyaan dengan 4 butir pilihan jawaban. Berdasarkan rumus kategori data, diperoleh hasil disribusi frekuensi aspek process dapat dilihat pada tabel 11.

Perolehan skor berdasarkan tabel 11 menunjukkan bahwa 11 sekolah ditinjau dari aspek process program pertukaran siswa sangat baik (100\%). Artinya bahwa 11 sekolah dari aspek process telah menyelenggarakan program pertukaran siswa.
Berdasarkan tabel 12, diperoleh persentase nilai yang dicapai sebesar $80,85 \%$ dengan kategori sangat baik.

\section{Aspek Product}

Butir Instrumen angket terdiri dari 6 butir pertanyaan dengan 4 butir pilihan jawaban. Berdasarkan rumus kategori data, diperoleh hasil disribusi frekuensi aspek product pada tabel berikut ini:

Perolehan skor berdasarkan tabel 13 menunjukkan bahwa 11 sekolah ditinjau dari aspek product program pertukaran siswa termasuk dalam kategori sangat baik (100\%). Artinya bahwa 11 sekolah memiliki perubahan pengetahuan dan keterampilan siswa dilihat dari aspek product pada program pertukaran siswa. 
Tabel 14. Nilai Pencapaian Aspek Input

\begin{tabular}{cccccc}
\hline Jumlah Responden & Jumlah Soal & Total Skor & NPK & Persentase (\%) & Keterangan \\
\hline 11 & 6 & 207 & 18,82 & 78,41 & Sangat Baik \\
\hline
\end{tabular}

Tabel 15. Distribusi Frekuensi Aspek Contex

\begin{tabular}{clccc}
\hline No & Interval Nilai & Frekuensi & $\mathbf{( \% )}$ & Kategori \\
\hline 1 & $\mathrm{X} \geq 15$ & 11 & 100 & Sangat Baik \\
2 & $15>\mathrm{X} \geq 12,5$ & 0 & 0 & Baik \\
3 & $12,5>\mathrm{X} \geq 10$ & 0 & 0 & Tidak Baik \\
$4 \quad \mathrm{X}<10$ & 0 & 0 & Sangat Tidak Baik \\
\hline Total & 11 & 100 & \\
\hline
\end{tabular}

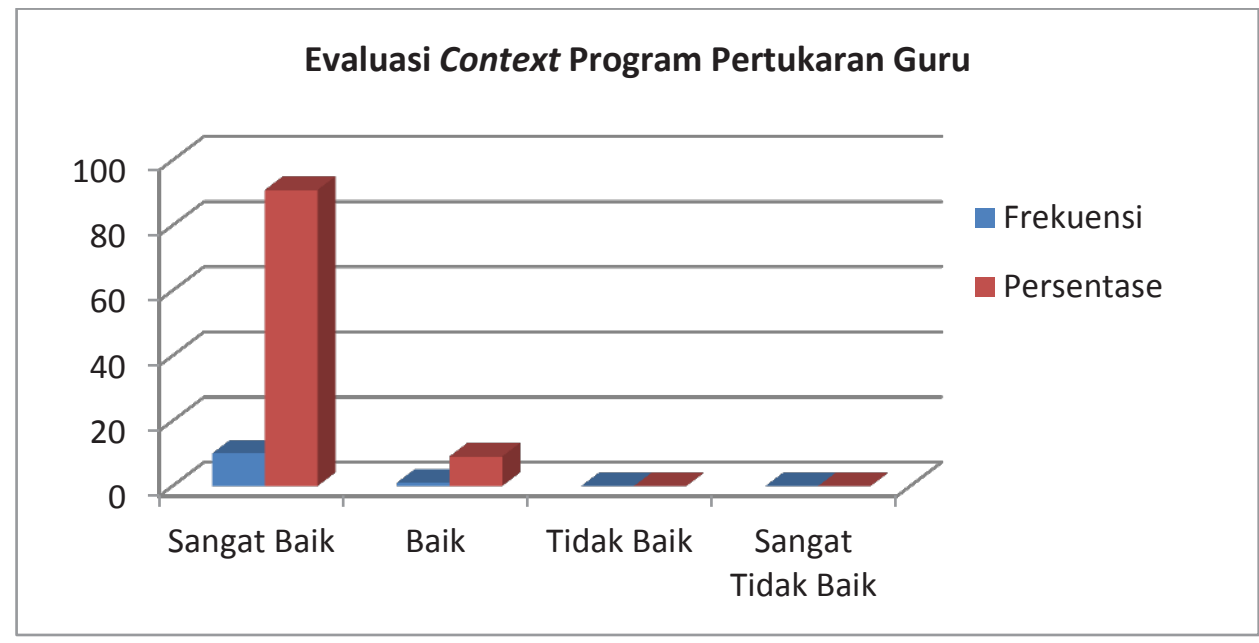

Gambar 4. Diagram Aspek Context

Tabel 16. Nilai Pencapaian Aspek Context

\begin{tabular}{cccccc}
\hline Jumlah Responden & Jumlah Soal & Total Skor & NPK & Persentase (\%) & Keterangan \\
\hline 11 & 5 & 172 & 15,64 & 78,2 & Sangat Sesuai \\
\hline
\end{tabular}

Berdasarkan tabel 14, diperoleh persentase nilai yang dicapai sebesar $78,41 \%$ dengan kategori baik.

\section{Program Pertukaran Guru}

\section{Aspek Context}

Butir Instrumen angket terdiri dari 5 butir pertanyaan dengan 4 butir pilihan jawaban. Berdasarkan rumus kategori data, diperoleh hasil disribusi frekuensi aspek context dapat dilihat pada tabel 15 .
Perolehan skor berdasarkan tabel 15 menunjukkan bahwa 10 unit sekolah ditinjau dari aspek context program pertukaran guru sangat baik $(90,91 \%) 1$ sekolah. 1 sekolah dalam kategori baik (9,09\%). Perolehan persentase diatas dapat dilihat dengan diagram Chart yang dapat dilihat pada gambar 4 .

Berdasarkan tabel 16, diperoleh persentase nilai yang dicapai sebesar $78,2 \%$ dengan kategori sangat sesuai. 
Tabel 17. Distribusi Frekuensi Aspek Input

\begin{tabular}{clccc}
\hline No & Interval Nilai & Frekuensi & $\mathbf{( \% )}$ & Kategori \\
\hline 1 & $\mathrm{X} \geq 11,0$ & 11 & 100 & Sangat Baik \\
2 & $11,0>\mathrm{X} \geq 7,5$ & 0 & 0 & Baik \\
3 & $7,5>\mathrm{X} \geq 4,0$ & 0 & 0 & Tidak Baik \\
$4 \quad \mathrm{X}<4,0$ & 0 & 0 & Sangat Tidak Baik \\
\hline Total & 11 & 100 & \\
\hline
\end{tabular}

Tabel 18. Nilai Pencapaian Aspek Input

\begin{tabular}{cccccc}
\hline Jumlah Responden & Jumlah Soal & Total Skor & NPK & Persentase (\%) & Keterangan \\
\hline 11 & 4 & 173 & 15,73 & 98,31 & Sangat Baik \\
\hline
\end{tabular}

Tabel 19. Distribusi Frekuensi Aspek Process

\begin{tabular}{clccc}
\hline No & Interval Nilai & Frekuensi & $\mathbf{( \% )}$ & Kategori \\
\hline 1 & $\mathrm{X} \geq 11$ & 10 & 90,91 & Sangat Baik \\
2 & $11>\mathrm{X} \geq 7,5$ & 1 & 9,09 & Baik \\
3 & $7,5>\mathrm{X}>4$ & 0 & 0 & Tidak Baik \\
4 & $\mathrm{X}<4$ & 0 & 0 & Sangat Tidak Baik \\
\hline Total & 11 & 100 & \\
\hline
\end{tabular}

Tabel 20. Nilai Pencapaian Aspek Process

\begin{tabular}{cccccc}
\hline Jumlah Responden & Jumlah Soal & Total Skor & NPK & Persentase (\%) & Keterangan \\
\hline 11 & 7 & 173 & 22,55 & 80,85 & Sangat Baik \\
\hline
\end{tabular}

\section{Aspek Input}

Butir Instrumen angket terdiri dari 7 butir pertanyaan dengan 4 butir pilihan jawaban. Berdasarkan rumus kategori data, diperoleh hasil disribusi frekuensi aspek input dapat dilihat pada tabel 17.

Perolehan skor berdasarkan tabel 17 menunjukkan bahwa 11 sekolah ditinjau dari aspek input program pertukaran guru sangat baik $(100 \%)$. Artinya bahwa 11 sekolah dari aspek input sangat mendukung terselenggaranya program pertukaran guru.

Berdasarkan tabel 18, diperoleh persentase nilai yang dicapai sebesar $98,31 \%$ dengan kategori sangat baik.

\section{Aspek Process}

Butir Instrumen angket terdiri dari $7 \mathrm{bu}-$ tir pertanyaan dengan 4 butir pilihan jawaban. Berdasarkan rumus kategori data, diperoleh hasil disribusi frekuensi aspek process dapat dilihat pada tabel 19 .

Perolehan skor berdasarkan tabel 19 menunjukkan bahwa 11 sekolah ditinjau dari aspek process program pertukaran siswa sangat baik (100\%). Artinya bahwa 11 sekolah dari aspek process telah menyelenggarakan program pertukaran siswa.

Berdasarkan tabel 20, diperoleh persentase nilai yang dicapai sebesar $80,85 \%$ dengan kategori sangat baik. 
Tabel 21. Distribusi Frekuensi Aspek Product

\begin{tabular}{clccc}
\hline No & Interval Nilai & Frekuensi & $\mathbf{( \% )}$ & Kategori \\
\hline 1 & $\mathrm{X} \geq 18$ & 10 & 90,91 & Sangat Baik \\
2 & $18>\mathrm{X} \geq 15$ & 1 & 9,09 & Baik \\
3 & $15>\mathrm{X} \geq 12$ & 0 & 0 & Tidak Baik \\
4 & $\mathrm{X}<12,0$ & 0 & 0 & Sangat Tidak Baik \\
\hline \multicolumn{2}{l}{ Total } & 11 & 100 & \\
\hline
\end{tabular}

Tabel 22. Nilai Pencapaian Aspek Product

\begin{tabular}{cccccc}
\hline Jumlah Responden & Jumlah Soal & Total Skor & NPK & Persentase (\%) & Keterangan \\
\hline 11 & 6 & 220 & 20 & 83,3 & Sangat Baik \\
\hline
\end{tabular}

Tabel 23. Distribusi Frekuensi Aspek Context

\begin{tabular}{clccc}
\hline No & Interval Nilai & Frekuensi & $\mathbf{( \% )}$ & Kategori \\
\hline 1 & $\mathrm{X} \geq 18$ & 11 & 100 & Sangat Baik \\
2 & $18>\mathrm{X} \geq 15$ & 0 & 0 & Baik \\
3 & $15>\mathrm{X} \geq 12$ & 0 & 0 & Tidak Baik \\
$4 \quad \mathrm{X}<12$ & 0 & 0 & Sangat Tidak Baik \\
\hline Total & 11 & 100 & \\
\hline
\end{tabular}

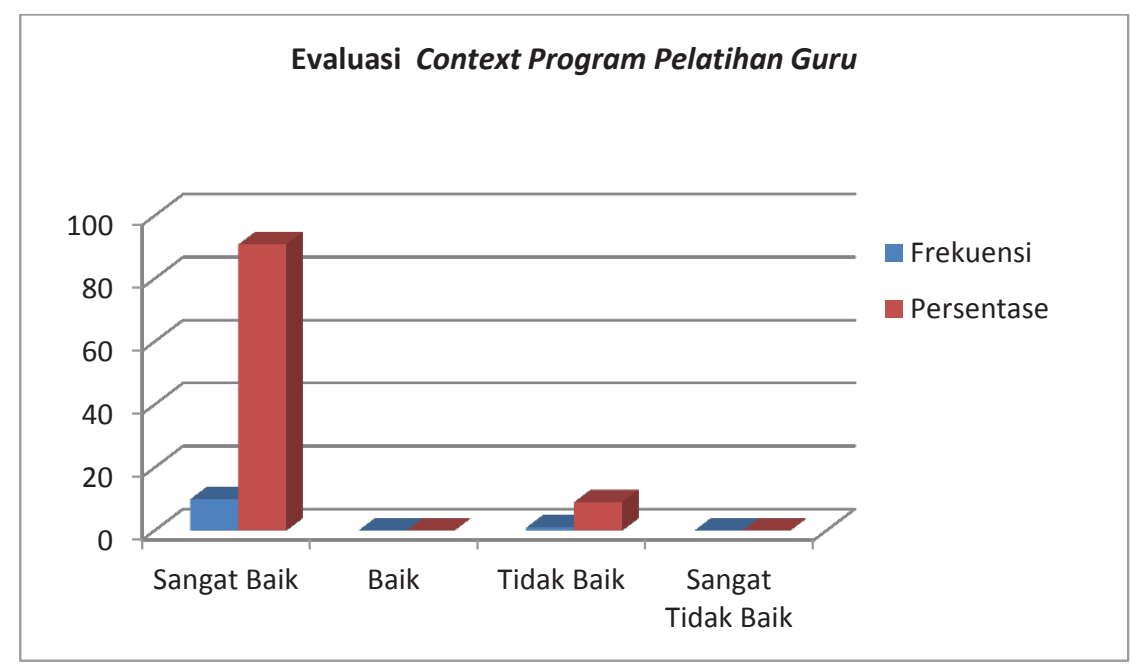

Gambar 5. Diagram Aspek Context

\section{Aspek Product}

Butir Instrumen angket terdiri dari 6 butir pertanyaan dengan 4 butir pilihan jawaban. Berdasarkan rumus kategori data, diperoleh hasil disribusi frekuensi aspek product dapat dilihat pada tabel 21 .

Perolehan skor berdasarkan tabel 21 menunjukkan bahwa 11 sekolah ditinjau dari aspek product program pertukaran guru termasuk dalam kategori sangat baik (100\%). Artinya bahwa 11 sekolah memiliki perubahan pengetahuan dan keterampilan bagi guru dilihat dari aspek product pada program pertukaran guru.

Berdasarkan tabel 22, diperoleh persentase nilai yang dicapai sebesar $78,2 \%$ dengan kategori sangat baik. 
Tabel 24. Nilai Pencapaian Aspek Context

\begin{tabular}{cccccc}
\hline Jumlah Responden & Jumlah Soal & Total Skor & NPK & Persentase (\%) & Keterangan \\
\hline 11 & 5 & 172 & 15,64 & 78,2 & Sangat Sesuai \\
\hline
\end{tabular}

Tabel 25. Distribusi Frekuensi Aspek Input

\begin{tabular}{clccc}
\hline No & Interval Nilai & Frekuensi & $\mathbf{( \% )}$ & Kategori \\
\hline 1 & $\mathrm{X} \geq 18$ & 11 & 100 & Sangat Baik \\
2 & $18>\mathrm{X} \geq 15$ & 0 & 0 & Baik \\
3 & $15>\mathrm{X} \geq 12$ & 0 & 0 & Tidak Baik \\
4 & $\mathrm{X}<12$ & 0 & 0 & Sangat Tidak Baik \\
\hline Total & 11 & 100 & \\
\hline
\end{tabular}

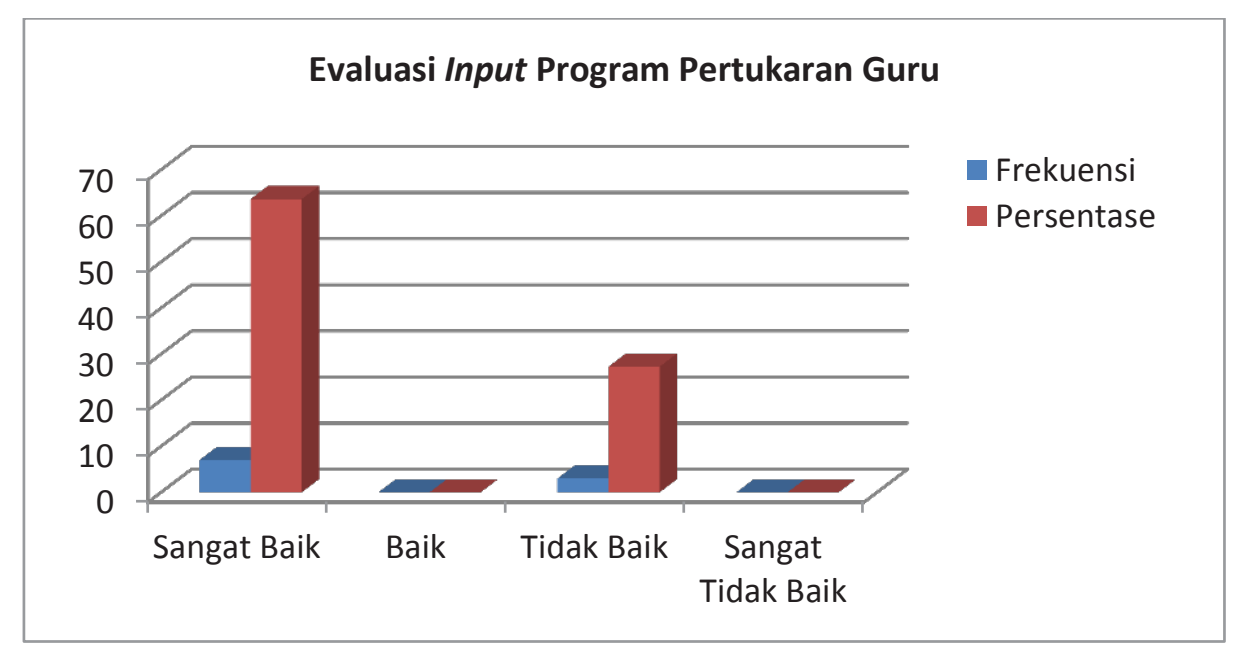

Gambar 6. Diagram Aspek Input

\section{Program Pelatihan Guru}

\section{Aspek Context}

Butir Instrumen angket terdiri dari 6 butir pertanyaan dengan 4 butir pilihan jawaban. Berdasarkan rumus kategori data, diperoleh hasil disribusi frekuensi aspek context pada tabel berikut ini:

Perolehan skor berdasarkan tabel 23 menunjukkan bahwa 10 sekolah ditinjau dari aspek context dari program pelatihan guru sangat baik $(90,91 \%), 1$ sekolah dalam kategori baik $(9,09 \%)$. Perolehan persentase diatas dapat dilihat dengan diagram Chart yang dapat dilihat pada gambar 5 .

Berdasarkan tabel 24, diperoleh persentase nilai yang dicapai sebesar $78,2 \%$ dengan kategori sangat sesuai.

\section{Aspek Input}

Butir Instrumen angket terdiri dari 7 butir pertanyaan dengan 4 butir pilihan jawaban. Berdasarkan rumus kategori data, diperoleh hasil disribusi frekuensi aspek input dapat dilihat pada tabel 25 .

Perolehan skor berdasarkan tabel 24 bahwa 11 sekolah ditinjau dari aspek input program pertukaran siswa berkategori sangat baik (100\%). Artinya bahwa 11 sekolah sangat mendukung terselenggaranya program pelatihan guru. Perolehan persentase diatas dapat dilihat dengan diagram Chart yang dapat dilihat pada gambar 6.

Berdasarkan tabel 26, diperoleh persentase nilai yang dicapai sebesar $77,66 \%$ dengan kategori sangat baik. 
Tabel 26. Nilai Pencapaian Aspek Input

\begin{tabular}{cccccc}
\hline Jumlah Responden & Jumlah Soal & Total Skor & NPK & Persentase (\%) & Keterangan \\
\hline 11 & 3 & 205 & 18,64 & 77,66 & Sangat Baik \\
\hline
\end{tabular}

Tabel 23. Distribusi Frekuensi Aspek Context

\begin{tabular}{clccc}
\hline No & Interval Nilai & Frekuensi & $\mathbf{( \% )}$ & Kategori \\
\hline 1 & $\mathrm{X} \geq 30$ & 8 & 72,73 & Sangat Baik \\
2 & $30>\mathrm{X} \geq 25$ & 0 & 0 & Baik \\
3 & $25>\mathrm{X} \geq 20$ & 0 & 0 & Tidak Baik \\
4 & $\mathrm{X}<20$ & 3 & 27,27 & Sangat Tidak Baik \\
\hline Total & 11 & 100 & \\
\hline
\end{tabular}

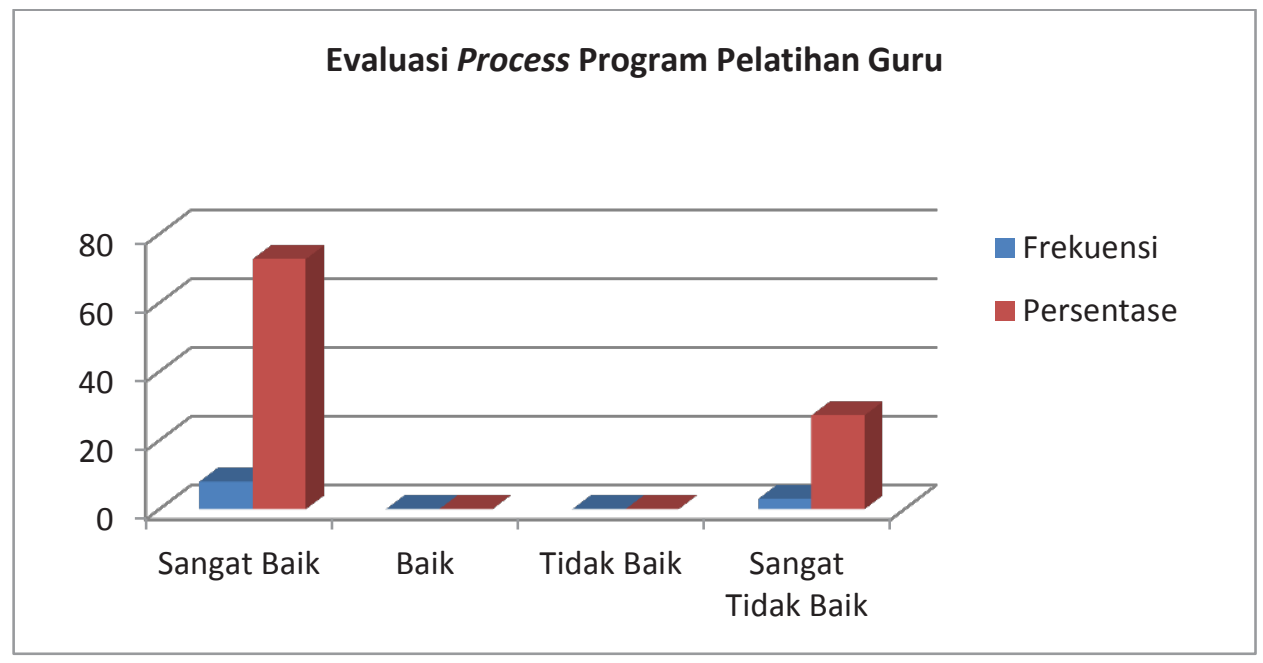

Gambar 7. Diagram Aspek Process

Tabel 26. Nilai Pencapaian Aspek Input

\begin{tabular}{cccccc}
\hline Jumlah Responden & Jumlah Soal & Total Skor & NPK & Persentase (\%) & Keterangan \\
\hline 11 & 10 & 292 & 26,55 & 66,37 & Baik \\
\hline
\end{tabular}

\section{Aspek Process}

Butir Instrumen angket terdiri dari 7 butir pertanyaan dengan 4 butir pilihan jawaban. Berdasarkan rumus kategori data, diperoleh hasil disribusi frekuensi aspek proces dapat dilihat pada tabel 27.

Perolehan skor berdasarkan tabel 26 menunjukkan bahwa 8 sekolah ditinjau dari aspek process program pelatihan guru termasuk dalam kategori sangat baik $(100 \%)$ dan 3 sekolah dalam kategori sangat tidak baik. Artinya bahwa 3 sekolah dari aspek process tidak menyelenggarakan program pelatihan guru. Perolehan persentase diatas dapat dilihat dengan diagram Chart yang dapat dilihat pada gambar 7.

Berdasarkan tabel 28, diperoleh persentase nilai yang dicapai sebesar $66,37 \%$ dengan kategori baik.

\section{Aspek Product}

Butir Instrumen angket terdiri dari 3 butir pertanyaan dengan 4 butir pilihan jawaban. Berdasarkan rumus kategori data, diperoleh hasil disribusi frekuensi aspek product dapat dilihat pada tabel 29. 
Tabel 29. Distribusi Frekuensi Aspek Product

\begin{tabular}{clccc}
\hline No & Interval Nilai & Frekuensi & $\mathbf{( \% )}$ & Kategori \\
\hline 1 & $X \geq 9,0$ & 8 & 72,73 & Sangat Baik \\
2 & $9,0>X \geq 7,5$ & 0 & 0 & Baik \\
3 & $7,5>X \geq 6,0$ & 0 & 0 & Tidak Baik \\
4 & $X<6,0$ & 3 & 27,27 & Sangat Tidak Baik \\
\hline Total & 11 & 100 & \\
\hline
\end{tabular}

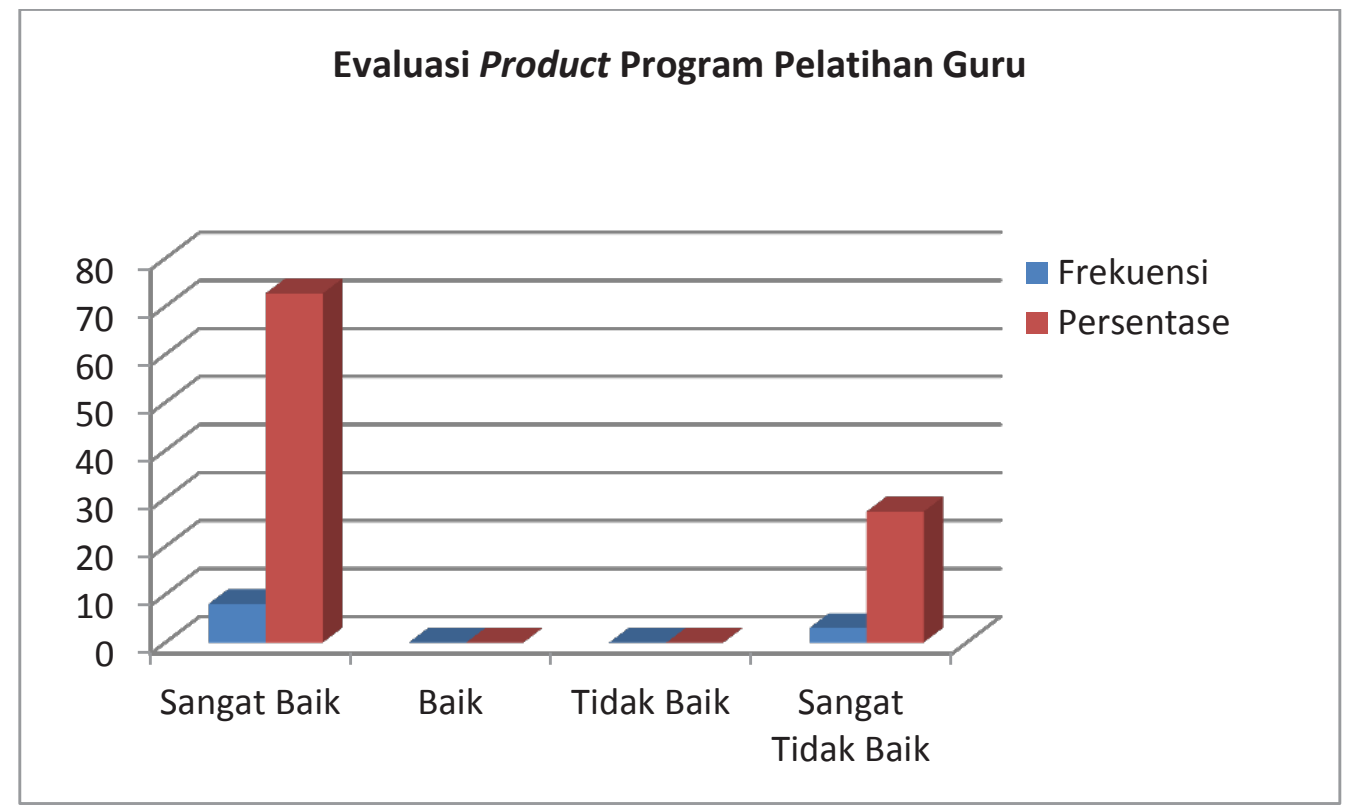

Gambar 8. Diagram Aspek Product

Tabel 30. Nilai Pencapaian Aspek Product

\begin{tabular}{cccccc}
\hline Jumlah Responden & Jumlah Soal & Total Skor & NPK & Persentase (\%) & Keterangan \\
\hline 11 & 3 & 84 & 7,64 & 63,66 & Baik \\
\hline
\end{tabular}

Perolehan skor berdasarkan tabel 29 menunjukkan bahwa 8 sekolah ditinjau dari aspek product program pertukaran guru termasuk dalam kategori sangat baik $(72,73 \%)$ dan 3 sekolah dalam kategori sangat tidak baik (27,27\%). Artinya bahwa 3 sekolah tidak mencapai tujuan program pelatihan. Perolehan persentase diatas dapat dilihat dengan diagram Chart yang dapat dilihat pada gambar 8 .

Berdasarkan tabel 30, diperoleh persentase nilai yang dicapai sebesar $66,37 \%$ dengan kategori baik.

\section{SIMPULAN DAN SARAN}

\section{Simpulan}

Berdasarkan permasalahan, tujuan penelitian, hasil analisis dan pembahasan yang telah dipaparkan, maka dapat disimpulkan bahwa: (1) Pelaksanaan program SEAMOLEC di SMK D.I. Yogyakarta dari ke empat program untuk aspek context termasuk dalam kategori sangat sesuai (program kolaborasi e-learning sebesar $75 \%$, program pertukaran siswa sebesar 98,31 , program pertukaran guru sebesar $78,2 \%$, pro- 
gram pelatihan guru sebesar $77,66 \%$ ), yaitu relevan dengan latar belakang dan tujuan program SEAMOLEC; (2) Pelaksanaan program SEAMOLEC di SMK D.I. Yogyakarta untuk aspek input termasuk dalam kategori sangat baik (program kolaborasi e-learning sebesar $64 \%$, program pertukaran siswa sebesar $80,85 \%$, program pertukaran guru sebesar 98,31, dan program pelatihan guru sebesar 63,62\%), yaitu kesiapan SDM di sekolah dan biaya pelaksanaan program SEAMOLEC; (3) Pelaksanaan program SEAMOLEC di SMK D.I. Yogyakarta untuk aspek process termasuk dalam kategori sangat sangat baik (program pertukaran siswa sebesar $80,85 \%$, program pertukaran guru sebesar $80,53 \%$, dan program pelatihan guru sebesar $66,37 \%$ ) yaitu dari segi waktu pelaksanaan. Sedangkan untuk program kolaborasi e-learning belum terlaksana di SMK D.I. Yogyakarta; (4) Pelaksanaan program SEAMOLEC di SMK D.I. Yogyakarta untuk aspek product termasuk dalam kategori sangat sangat baik (program pertukaran siswa sebesar $78,4 \%$, program pertukaran guru sebesar $83,33 \%$, dan program pelatihan guru sebesar $63,66 \%$ ), yaitu dari segi hasil program. Sedangkan untuk program kolaborasi e-learning tidak memiliki hasil karena program tersebut belum terlaksana di SMK D.I. Yogyakarta; (5) Faktor pendukung program SEAMOLEC adalah adanya dukungan dari sekolah seperti sarana prasarana laboratorium komputer yang lengkap, dukungan kepala sekolah, dan penyelenggaraan pelatihan bahasa Thailand untuk siswa dan guru; (6) Faktor penghambat program SEAMOLEC adalah dana yang sangat kurang untuk melaksanakan program pertukaran siswa, pertukaran guru, dan, pelatihan guru, sedangkan untuk program kolaborasi $e$ learning faktor penghambatnya adalah kurangnya penguasaan bahasa Inggris bagi siswa.

\section{Saran}

Berdasarkan hasil penelitian yang diperoleh, peneliti perlu memberikan saran-saran kepada sekolah dan pihak-pihak lain yang terkait yaitu: (1) Kelengkapan sarana dan prasarana atau laboratorium komputer sudah baik, namun jumlah komputer yang ada sebaiknya ditambah sesuai dengan jumlah siswa; (2) Pengenalan edmodo kepada siswa perlu dit- ingkatkan, minimal siswa mampu berkolaborasi dengan siswa lainnya dalam satu sekolah; (3) Sekolah meningkatkan kerjasama dengan sekolah luar negeri lainnya tidak hanya ASEAN namun juga eropa guna peningkatan pengetahuan, prestasi dam kualitas sekolah dalam program pertukaran siswa dan guru; (4) Memperbanyak materi pelatihan bagi guru dalam program pelatihan guru berbasis teknologi informasi dan komunikasi yang mendukung kegiatan pembelajaran; (5) Kerjasama antara sekolah, komite sekolah, guru, siswa dan orang tua perlu ditingkatkan untuk mendukung kelancaran program yang diikuti oleh sekolah.

\section{DAFTAR PUSTAKA}

Arief, \& Khusnul, R. (2013). Implementasi program teacher exchange dalam meningkatkan profesionalisme guru di MAN 3 Malang. Fakultas Ilmu Pendidikan Universitas Negeri Malang.

Bansal, H. (2009). Teacher training concept. Delhi: S.B. Nangia.

Berg, G.A. (2002). Why distance learning? Higher Education administrative practice. Westport, CT: Praeger.

Chapman, Thiel. (1999). An affordable teacher exchange program. Jurnal Phi Delta Kappan Volume 80. ISSN 00317217

Clark Aldrich. (2004). Simulations and the future of learning. Sanfrancisco: Pfiffer.

Daradoumis, T et.al. (2009). Intelligent collaboration e-learning systems and applications. Berlin: Springer

Direktorat Pembinaan Sekolah Kejuruan. (2006). Penyelenggaraan sekolah menengah kejuruan bertaraf internasional. Jakarta: Departemen Pendidikan Nasional.

Endang, M. (2013). Metode penelitian pendidikan. Yogyakarta: Alfabeta.

Fitzpatrick, J. L., Sanders, J. R., \& Worthen, B. R. (2011). Program evaluation alternative approaches and practical guidelines (4th edition). New Jersey: Pearson. 
Graham, M. \& Scarborough, H. (1999). Computer mediated communication and collaborative learning In an undergraduate distance education environment. Australian Journal of Educational Technology. 1999. 15(1): 20-46. http://www.ascilite. org.au/ajet/ajet15/graham.html

Hansel B. (2007). The exchange student survival kit. Boston-London: Intercultural Press.

Horton, W. (2001). Leading e-learning. USA: American society for training and development (ASTD).

Mugara, R. (2011). Meningkatkan kompetensi guru melalui penguasaan teknologi informasi dan komunikasi (TIK). Disertasi. Universitas Pendidikan Indonesia.

Mulyono. (2010). Konsep pembiayaan pendidikan. Yogyakarta: Ar-Ruzz

Niputu, S. (2009). Implementasi kebijakan rintisan sekolah bertaraf internasional (studi multsitus pada tiga sekolah menengah atas negeri di bali. Tesis Pasca Sarjana Universitas Negeri Malang. http://karya-ilmiah.um.ac.id/index.php/ disertasi/article/view/3720

Peringkat pendidikan indonesia di dunia. Diakses tanggal 4 September 2013 dari www.kampus.okezone.com.

Rahman, A. (2009). Pembinaan profesional Guru SMK (kajian kualitatif pada SMK di Bandung). Jurnal Tabularasa PPS UNIMED. Vol.6 No.1, Juni 2009.
Ranga, R, \& Bhaskara D. (2008). Methods of teacher training. New Delhi: Discovery publising house.

Rika, I.W. (2011). Modal budaya mutu pada rintisan sekolah bertaraf internasional di Propinsi Bali. Disertasi tidak diterbitkan. Universitas Negeri Malang. Diakses tanggal 20 Oktober 2013 dari http:// karya- ilmiah.um.ac.id/index.php/disertasi/article/view/18027.

Schewe, O. (2012). The exchange student guidebook. Everything you'll need to spend a succesfull high school year abroad. USA: iUniverse.

Suhartini. (2007). Perspektif global. Jurnal Majora. Yogyakarta. Universitas Negeri Yogyakarta.

Sukardi. (2011). Evaluasi pendidikan prinsip dan oprasionalnya. Jakarta: Bumi aksara.

Turner, T,. et al. (2003). Starting to teach in the secondary school. A companion for the newly qualified teacher. USA: RoutledgeFalmer

Wanwan, M. et al. (2013). Jurnal Teknologi (Social Sciences) 65:2 (2013), 67-74. 65:2 www.jurnalteknologi.utm.my eISSN 2289-5434 | Universiti Teknologi_Malaysia. http://www.jurnalteknologi.utm.my/index.php/jurnalteknologi/ article/viewFile/2351/1877

Wagner, S. (2009). Inclusive programming: for high school students with autism or asperger's syndrome. USA: future horizon. 